\title{
Maintenance of wetland plant communities: the role of the seed bank in regeneration of native plants
}

\author{
Francielli Bao ${ }^{1 *}$ (1), Marco Antonio de Assis ${ }^{1}$ (i) and Arnildo Pott ${ }^{2}$ (i)
}

Received: March 11, 2020

Accepted: August 14, 2020

\begin{abstract}
Exotic grasses have been introduced into wetlands and can compete with native plants due to their high tolerance of flood and dry periods. Flooding can facilitate seed dispersal of exotic species and reduce the diversity of native species. We compared two grasslands to assess whether seed banks can maintain the diversity of native plants in wetlands with introduced exotic plants. We recorded a total of 136 species and a predominance of annual plants in the seed bank and vegetation together. The seed bank had high species diversity independently of the dominance of the exotic Urochloa humidicola in the vegetation. The seed banks of the native and cultivated grasslands differed significantly with a positive correlation for aquatic plants in the native grassland and negative correlation in the cultivated grassland. The seed bank revealed potential to maintain the diversity of native species in the cultivated grassland since the flood and dry seasons promoted the presence of distinct species in the seed bank, but lower richness in the vegetation reflects a dependence on the germination stage. The seasonality of flood and dry periods influences distinct growth forms, increasing the diversity of the seed bank and the vegetation.
\end{abstract}

Keywords: exotic plants, life cycle, grasslands, growth forms, seasonal savanna

\section{Introduction}

Wetlands are composed of a diversity of perennial grasses and annual herbs, which vary in abundance according to flood and drought periods (Touzard et al. 2002). The Brazilian Pantanal is dominated by open fields under periodical floods from local rains and river overflow (Pott \& Silva 2015). The seasonality is a determining factor in the establishment of the vegetation due to the direct effects of soil moisture on germination and establishment of seedlings (Baskin \& Baskin 2014). The variations in water regime can change over seasons and influence the formation of seasonal communities of distinct plants (Casanova \& Brock 1990;
Harwell \& Havens 2003). During the flood season, the vegetation is structured by submerged and floating aquatic macrophytes (Pott \& Pott 2004; Bao et al. 2018a), and as the water recedes, the grassland becomes drained, and the vegetation is rapidly dominated by emergent species from the seed bank (Bao et al. 2017).

Grasses have high representation in these wetlands and coexist with the other groups of plants over the seasons (Bao et al. 2014; 2015; 2017; 2018a; Pott \& Silva 2015; Souza et al. 2016). The predominance of grasses, however, makes these areas ideal for grazing activities. The search for species resistant and able to compete with aquatic plants during floods leads to the introduction of exotic grasses in natural grasslands worldwide (Bossuyt et al. 2006; Fisher et

1 Instituto de Biociências, Universidade Estadual Paulista, 13506-752, Rio Claro, SP, Brazil

2 Programa de Pós-Graduação em Biotecnologia e Biodiversidade, Universidade Federal de Mato Grosso do Sul, 79070-900,

Campo Grande, MS, Brazil

* Corresponding author: franbao@yahoo.com.br 
al. 2009; Ma et al. 2012). In the Pantanal, the introduction of Urochloa humidicola, utilized as grazing for cattle, became recurrent due to its ability to tolerate flooding (Mattos et al. 2005; Souza et al. 2006; Bao et al. 2020) and high regrowth and vegetative propagation potential (Michelan et al. 2010). The morphology of its diaspores (with palea and glume well coupled) provides slow absorption of water, allowing it to stay dormant in the field for extended periods (Montorio et al. 1997). Widespread dispersal of U. humidicola can lead to increased dominance in the community at the expense of native species in the vegetation (Bao et al. 2015). However, for the seed bank, although it can store seeds of exotic plants, the seasonal floods can act in favor of maintaining diversity, bringing seeds from local native plants and neighboring areas (Bao et al. 2014).

The dispersal of seeds and the formation of the seed banks dominated by exotic species are a great concern in wetlands, as connected waterways can act as corridors increasing the spread of the species through hydrochory (Nathan \& Muller-Landau 2000), finally modifying the local scale and patterns of the native plant community (Whittaker et al. 2001). Wetlands and hydrologic connectivity within and among wetland areas can facilitate changes in the composition and diversity of the vegetation by providing dispersal corridors (Middleton 2002), and modify the composition of the local seed banks (Boedeltje et al. 2002; Baldwin et al. 2010).

In a microcosms experiment with five aquatic macrophytes (Sagittaria guayanensis, Limnocharis flava, Hydrocleys parviflora and Pontederia subovata) we showed that the presence of aquatic macrophytes can increase the mortality of $U$. humidicola (c. $70 \%$ ) under three months, due to decreased of luminosity (Bao et al. 2020). In this sense, it is important to verify the distribution and abundance of aquatic macrophytes within the seed bank in grasslands considering how plant species invasion alters the vegetation and the seed bank. For this study, we compared the vegetation and the seed bank of seasonally flooded grassland dominated by the exotic U. humidicola and another composed of native grasses. The following hypotheses guided this research:

The seed bank does not differ in richness and abundance between native and cultivated grasslands. We believe that the maintenance of these variables occurs by annual plants present in the soil in both grasslands (contrasting life cycles). The seed bank and the vegetation do not present similarity: independently of the grassland or seasonal period, the seed bank has greater diversity, due to local seeds and neighboring areas that accumulate over the years. In the seed bank, the growth forms of aquatic and amphibious plants have higher distribution in native grasslands and terrestrial forms in cultivated grasslands. However, in the vegetation, we expect a positive correlation of terrestrial forms in both grasslands. We believe that the history of cultivation (over 15 years) of $U$. humidicola in cultivated grasslands can be decreasing the presence of aquatic macrophytes in the seed bank (contrasting growth forms).

\section{Materials and methods}

\section{Study area}

The present study was carried out in the sub-region of Abobral, Pantanal, Mato Grosso do Sul (Central-West Brazil, Fig. 1A). The climate of the region is tropical sub-humid, with a mean annual temperature of $26^{\circ} \mathrm{C}$ and an average annual rainfall of $1100 \mathrm{~mm}$ (Allem \& Valls 1987; Silva \& Abdon 1998). The Brazilian Pantanal is regulated by an annual flood pulse, the seasonality in this region is marked by well-defined periods of rain/flood (between December and May) and dry (between July and November), with pluvial and fluvial fluctuations, with maximum $(7.34 \mathrm{~m})$ and minimum level $(2.37 \mathrm{~m}$ ) of the Miranda river (data collected at Base de Estudos do Pantanal - BEP, between 2005 and 2015, Fig.1B). The ground level can vary between 1 to $60 \mathrm{~cm}$ (Allem \& Valls 1987; Silva \& Abdon 1998). Such variation of topography added to the different sites of hydrological regime form permanent and periodically flooded zones (Pott \& Silva 2015).

To examine the effect of seasonality on the grassland over time, we conducted four samplings on the hydrophases (dry/2013-2014 and flood/2014-2015) of the Pantanal: two at the end of the dry period (September) and two at the end of the flood period (July) (Fig.1B). These native grasslands are traditionally utilized as pastures and were partially replaced by cultivated grassland using the exotic Urochloa humidicola (Rendle) Morrone \& Zuloaga (Poaceae). This species was first introduced 15 years ago.

Samplings were made in eight seasonal ponds, distant 1 $\mathrm{km}$ between each other: four located in a cultivated grassland dominated by the exotic $U$. humidicola and the others four in native grassland (Fig. 1A). To achieve the widest amplitude in capture of seeds and species richness, in each seasonal pond we set three transects according to the flood level: one placed in the middle of the pond (low), one on the pond edge (mid) and another most external to the pond (high), keeping a distance between them ca. $10 \mathrm{~m}$ horizontally and ca. $30 \mathrm{~cm}$ vertically (Fig. 1C). The transects were established using as reference the watermark of the flood level on fence poles and arboreal plants, and the points were marked in the first year of the study, at the end of flooding, when seasonal ponds are formed (cf. Bao et al. 2014).

\section{Vegetation and seed bank sampling}

For analysis of the established vegetation, we performed a sampling of plant cover using the method of the percentage of species present in the study area (e.g. Dolle \& Schmidt 2009). In each transect, we sampled five random replicates for evaluation of plant cover, totaling 1 sample per pond. 
Within a delimited area of $0.50 \times 0.50 \mathrm{~m}$, we made the visual estimate of the percentage cover of each species, and for more precise estimates each quadrat was subdivided with strings into quarters, and the observation was always made by the same person.

In each sampling quadrat of plant cover, we took three soil samples, each with $20 \times 20 \mathrm{~cm}$ and $3 \mathrm{~cm}$ deep, with a shovel (cf. Bao et al. 2014). Each soil sample was submitted to a distinct method of evaluation of the seed bank. To increase seed sampling accuracy we used three methods: Method I -seedling emergency in the greenhouse (for knowledge of viable seeds) - we spread the soil samples in plastic trays $(30 \mathrm{~cm} \times 30 \mathrm{~cm} \times 10 \mathrm{~cm}$ ), over a $2 \mathrm{~cm}$ layer of sterilized washed sand under ambient temperature, the seedlings of germinated seeds were counted, identified and removed, to avoid competition from new seedlings (Thompson et al. 1997). Method II - manual counting of seeds (to determine the total number of seeds in the sediment) - for this, we washed the soil through a set of sieves with three mash sizes $(0.25 \mathrm{~mm}, 0.35 \mathrm{~mm}$ and $0.50 \mathrm{~mm})$ to trap seeds of distinct sizes (Bonis et al. 1995; Mcfarland \& Shafer 2011), the retained seeds were fixed in alcohol $50 \%$ and preserved and, in the laboratory, the seeds were counted and identified under a stereoscopic microscope; Method III -submerged trays with soil to check the emergence of aquatic macrophyte seedlings (for the knowledge of the aquatic community) - seedling emergence was determined by spreading soil samples in plastic trays $(30 \mathrm{~cm} \times 30 \mathrm{~cm} \times 10 \mathrm{~cm})$ and then samples were submerged in tanks under $90 \mathrm{~cm}$ of water (flood) for three months (we removed filamentous algae when necessary).

The identification of the species was made by comparison with specimens in the Herbarium CGMS of Universidade Federal de Mato Grosso do Sul (UFMS), consulting specialized books (e.g. Pott \& Pott 1994; Pott \& Pott 2000; Kissmann \& Groth 1992; 1995; 1997) and identification manuals (e.g. Gil \& Bove 2006; Groth 1983; Kaul 1978; 1985; Souza \& Giulietti 2014), and collaboration from specialists on plants of the Pantanal. Species were presented according to APG IV- Angiosperm Phylogeny Group (2016) and Smith et al. (2006) for Lycophytes. We classified species germinated from the seed bank according to their life cycle (perennial or annual) and growth form (aquatic, amphibious and terrestrial) ( $c f$. Pott \& Pott 1994; Pott \& Pott 2000).

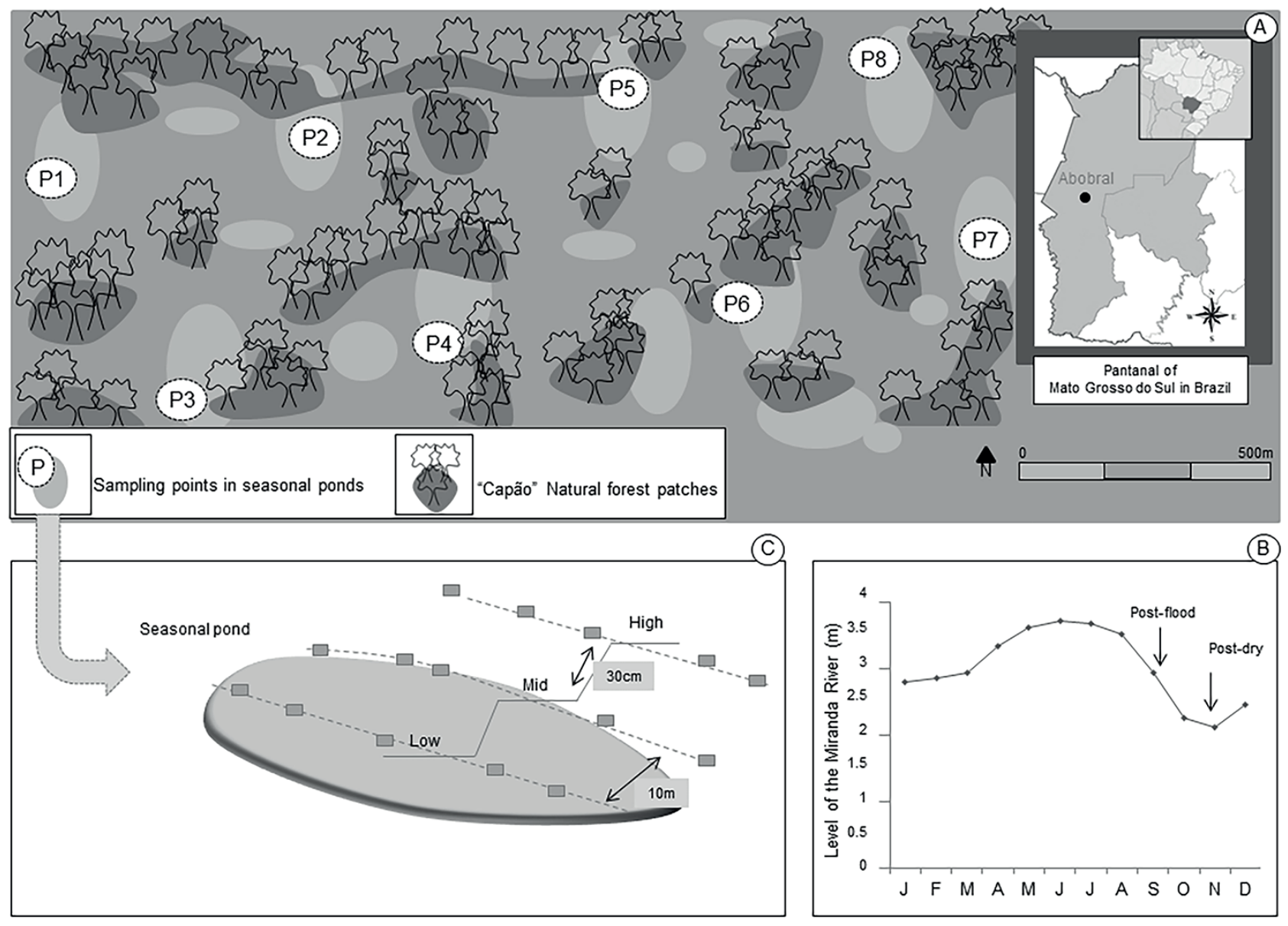

Figure 1. Seasonally flooded grassland in the Pantanal wetland (Central-West Brazil). (A) Sampling points including eight seasonal ponds (P1, P2, P3 and P4 in grassland dominated by U. humidicola, and P5, P6, P7 and P8 in native grassland), (B) representation of the transects following the topographic levels (low, mid and high) in each sampled pond, with five random samples, (C) mean monthly level of the Miranda River, arrows showing the sampled seasonal periods (dry and flood), between the years 2005-2015. 


\section{Statistical analysis}

For the first hypothesis, with richness and abundance data, we used the mean number of individuals of each species in the two-seasonal flood-dry cycles and calculated the total sum of abundance per sampling plot. For the first hypothesis, to describe the plant community, with richness and abundance values as response variables, we constructed a two-way ANOVA model with grassland type (native and cultivated) and life cycle (annual and perennial plants) as predictors.

For the second hypothesis, the data of species abundance and relative cover in the seed bank and the vegetation in each grassland type and seasonal period were ordinated by NonMetric Multidimensional Scaling (NMDS), utilizing the BrayCurtis distance. To decide how many solutions of NMDS would be utilized as dependent variables in a Multivariate Analysis of Variance (MANOVA), we compared $r^{2}$ values from linear regression of original values of the matrix of similarity with that obtained from ordination in one, two, or three solutions. The best solution had the highest $r^{2}$ value with the lowest value of stress. However, for graphical visual performance on compositional distribution between the seed bank and vegetation vs seasonal period (flood and dry) and grassland type (native and cultivated), we chose to use two-dimensional solution. MANOVA was used to determine if there were significant mean differences in a set of data through Pillai-Trace statistics. In addition, the similarity among sampled sites according to the floristic composition of soil seed bank and vegetation (data of grassland types and seasonal periods) were determined using the Similarity Percentage. We utilized ANOVA to compare effects of native and cultivated grasslands, and seasonal periods upon species relative abundance of seeds and relative cover. Finally, the species diversity of the vegetation and seed bank was calculated using the Shannon diversity index to evaluate the effect of seasonal periods (flood and dry) on diversity in each grassland type (native and cultivated). The analysis of variance (One-Way ANOVA) and the Tukey test were applied to verify significant mean differences.

Finally, for the third hypothesis, we applied analyses of redundancy (RDA) to examine if the growth forms (aquatic, amphibious and terrestrial) are related to the distribution of species composition of the seed bank and the vegetation between native and cultivated grassland. To select the growth forms for the analysis, we considered the germination and ecological requirements of the plant species to become established during the flood and dry season (analysed together). The significance tests of RDAs were done by an analysis of variance (Two-Way ANOVA). All analyses were in R environment ( $\mathrm{R}$ Development Core Team 2020), using the packages BiodiversityR (Kindt \& Coe 2005), vegan (Oksanen et al. 2017), permute (Simpson 2016) and lattice (Deepayan 2008).

\section{Results}

\section{Floristic}

We recorded 136 species in the plant community, 120 species in the native grassland (33 exclusives) and 103 species in the cultivated grassland dominated by U. humidicola (12 exclusives). Most species were in the Poaceae family (24 species), followed by Cyperaceae (16), Leguminosae (11), Asteraceae, Euphorbiaceae and Malvaceae (eight), Alismataceae and Plantaginaceae (seven each). Together these represented over $50 \%$ of the species found in this community (Tab. S1 in supplementary material).

Of the 120 species present in the seed bank $60 \%$ annuals and $40 \%$ were perennials. The richness of life cycles in the seed bank between grasslands types did not differ (ANOVA: $\mathrm{F}_{4.15}=214.310, \mathrm{p}=0.217$, Fig. $2 \mathrm{~A}$ ). The abundance of annual species in the seed bank was significantly higher compared to perennials (ANOVA: $F_{4.15}=423.333, p<0.001$, Fig. $2 B$ ), but did not differ between native and cultivated grasslands (ANOVA: $F_{4.15}=28.128, p=0.341$, Fig. $2 B$ ). The five species of highest abundance in the seed bank in both grasslands were annual plants: Hyptis brevipes (10.467 seeds), Richardia grandiflora (8.962), Rotala ramosior (8.298), Ludwigia octovalvis (8105) and Helanthium tenellum (5766).

Of the 104 species in the vegetation $60 \%$ were annuals and $40 \%$ were perennials. In the seed bank, annual species had the highest richness in native grassland (51 spp.), differing in richness as for perennial species (ANOVA: $\mathrm{F}_{4.15}=$ 62.10, $p<0.001$, Fig. $2 C$ ) and grassland type (ANOVA: $\mathrm{F}_{4.15}=$ 50.59, $\mathrm{p}<0.001$, Fig. $2 C$ ). For vegetation cover, we did not detect differences between life cycle (ANOVA: $\mathrm{F}_{4.15}=6.135$, $p=0.0234$, Fig. 2D) or type of grassland (ANOVA: $F_{4.15}=$ $11.560, p=0.351$, Fig. 2D). The five species with the highest average cover in both types of grasslands were the grasses Urochloa humidicola (53.4\%), Digitaria fuscescens (52.1\%), Axonopus purpusii (42.2\%), Reimarochloa acuta (41.2\%) and Paspalum almum (31.2\%).

\section{Similarity and diversity}

The similarity between the seed bank and the vegetation in the native and cultivated grassland was under $50 \%$ when seasonality was analysed separately. In flood and dry seasonal periods, it was $49 \%$ and $47 \%$ in native grassland and, $39 \%$ and $27 \%$ in cultivated grassland, respectively (Fig. 3).

In the flood season, the seed bank composition differed from the vegetation in both grassland types; native (MANOVA: Pillai-Trace $=0.087 ; \mathrm{F}_{2.242}, \mathrm{p}<0.001$, Fig. $3 \mathrm{~A}$ ) and cultivated (MANOVA: Pillai-Trace $=0.175 ; \mathrm{F}_{2.242}, \mathrm{p}<0.001$, Fig. 3B). In both grasslands, there was higher species diversity in the seed bank $(\mathrm{p}<0.001, \mathrm{Tab} .1)$. The individual contribution of each species in the similarity between seed bank and vegetation was below $2 \%$. In native grassland, 
Bacopa myriophylloides (1.54\%), Rotala ramosior (1.32\%), Bacopa australis (1.21\%) and Helanthium tenellum (1.02\%), were the most similar species; and in cultivated, $R$. ramosior (1.92\%), Cyperus surinamensis (1.33\%), C. subsquarrosus $(1.30 \%)$ and the exotic U. humidicola (1.25\%).

In the dry season no similarity was detected in native (MANOVA: Pillai-Trace $=0.0867 ; \mathrm{F}_{2.242}, \mathrm{p}<0.001$, Fig. $3 \mathrm{C}$ ) and cultivated grassland (MANOVA: Pillai-Trace $=0.0921$, $\mathrm{F}_{2.242}, \mathrm{p}<0.001$, Fig. $3 \mathrm{~d}$ ). The most similar species in native grassland were $D$. fuscescens $(7.1 \%), R$. grandiflora $(9.3 \%)$, A. purpusii (9.8\%) and Borreria eryngioides (10\%), and in cultivated, Isoetes pedersennii (5.2\%), U. humidicola (5.5\%), L. octovalvis (6.2\%) and Euploca filiformis (7.1\%).

To verify the absence of species that could be in the vegetation during the flood or dry seasonal periods, we made an analysis together (dry + flood). Despite the seed bank and the vegetation having increased their similarity to $57 \%$ in native and $45 \%$ in cultivated grassland, they continued to differ significantly in both grasslands, native (MANOVA: Pillai-Trace $=0.434, \mathrm{~F}_{2.242}, \mathrm{p}<0.001$ ) and cultivated (MANOVA: Pillai-Trace $=0.460, \mathrm{~F}_{2.242}, \mathrm{p}<0.001$ ). The index of species diversity increased; nevertheless the diversity in the seed bank remained superior in both grasslands $(\mathrm{p}<0.001$, Tab. 1), without effect of the seasonality.

\section{Correlation of the growth forms with the seed bank and vegetation}

Groups of plants were selected to explain how distinct growth forms (aquatic, amphibious and terrestrial) were related to species distribution between grasslands. In the seed bank, there was a clear split of native and cultivated grasslands (Fig. 4A). There was a positive correlation in aquatic plants (41.3\%) in native grassland (91.08 seeds), but negative in cultivated (52.96 seeds). The opposite occurred with terrestrial plants, being positive for cultivated (142.98 seeds) and negative for the native grasslands (110.61 seeds). Aquatic and terrestrial plants were inversely correlated to both grasslands (ANOVA: $\mathrm{F}_{3.17}=17.883$, $\mathrm{p}<0.001$, Fig. $4 \mathrm{~A})$. Nevertheless, in terms of diversity, the seed bank was similar between the native and cultivated grasslands (Tab. 1). The amphibious species were abundant in both
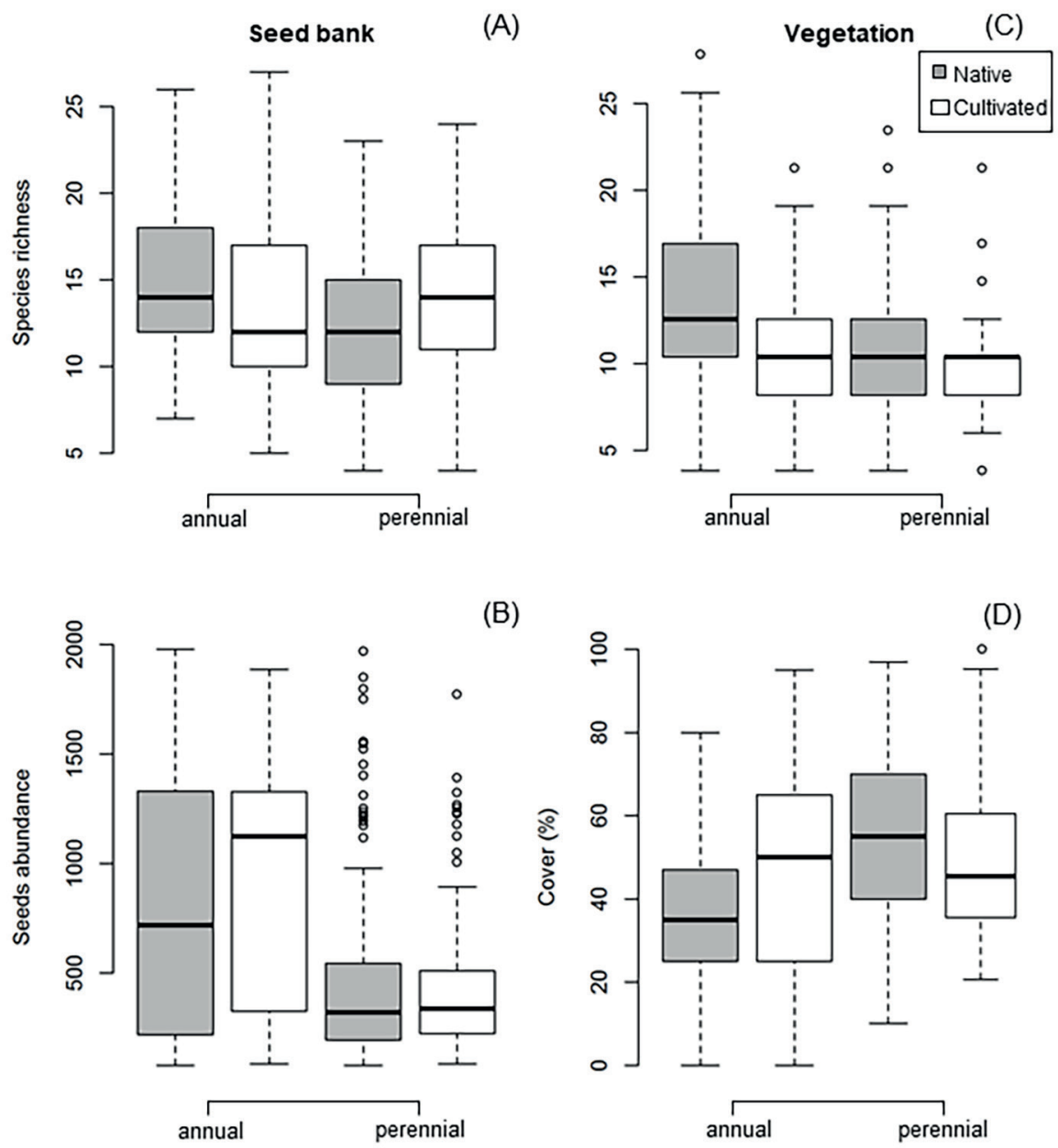

(B)

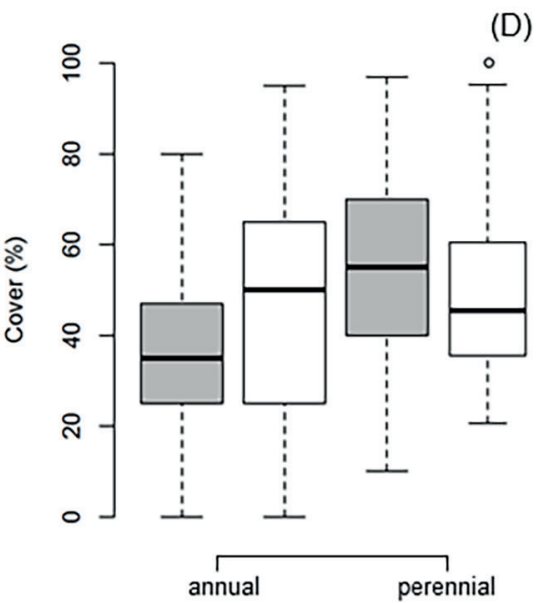

Figure 2. Occurrence of annual and perennial species regarding richness (A) and mean abundance of seeds (B), species richness (C) and mean vegetation cover (D), between native and cultivated grassland in the seed bank and in the vegetation, in the Pantanal wetland (Central-West Brazil). 
grassland types; the species Isoetes pedersenii (13.1\%), Rotala ramosior (12\%), E. minima (10.4\%), Bacopa australis and Schoenoplectiella supina (5 \% each) correlated positively (Fig.4A).

In the vegetation there was no separation of grassland types. The occurrence of terrestrial plants (52.2\%) was positively related to the axis RDA 2 including the higher composition of the plants present in cultivated grassland, differing from amphibious (28.7\%) and aquatic plants
(20.9\%) (ANOVA: $\mathrm{F}_{3.17}=2.917, \mathrm{p}<0.001$, Fig. 4B). The grasses U. humidicola (15.2\%), A. purpusii (9.3\%), D. fuscescens (7.4\%), R. acuta (6.6\%), Cynodon dactylon (6.1\%), P. almum (5.5\%) and of the emergent $R$. grandiflora and Diodia kuntzei (5\% each), H. brevipes, R. ramosior and Croton trinitatis ( $4 \%$ each) were the most influent species in the distribution of the species, enhancing the similarity between native and cultivated grassland (Fig.4B).
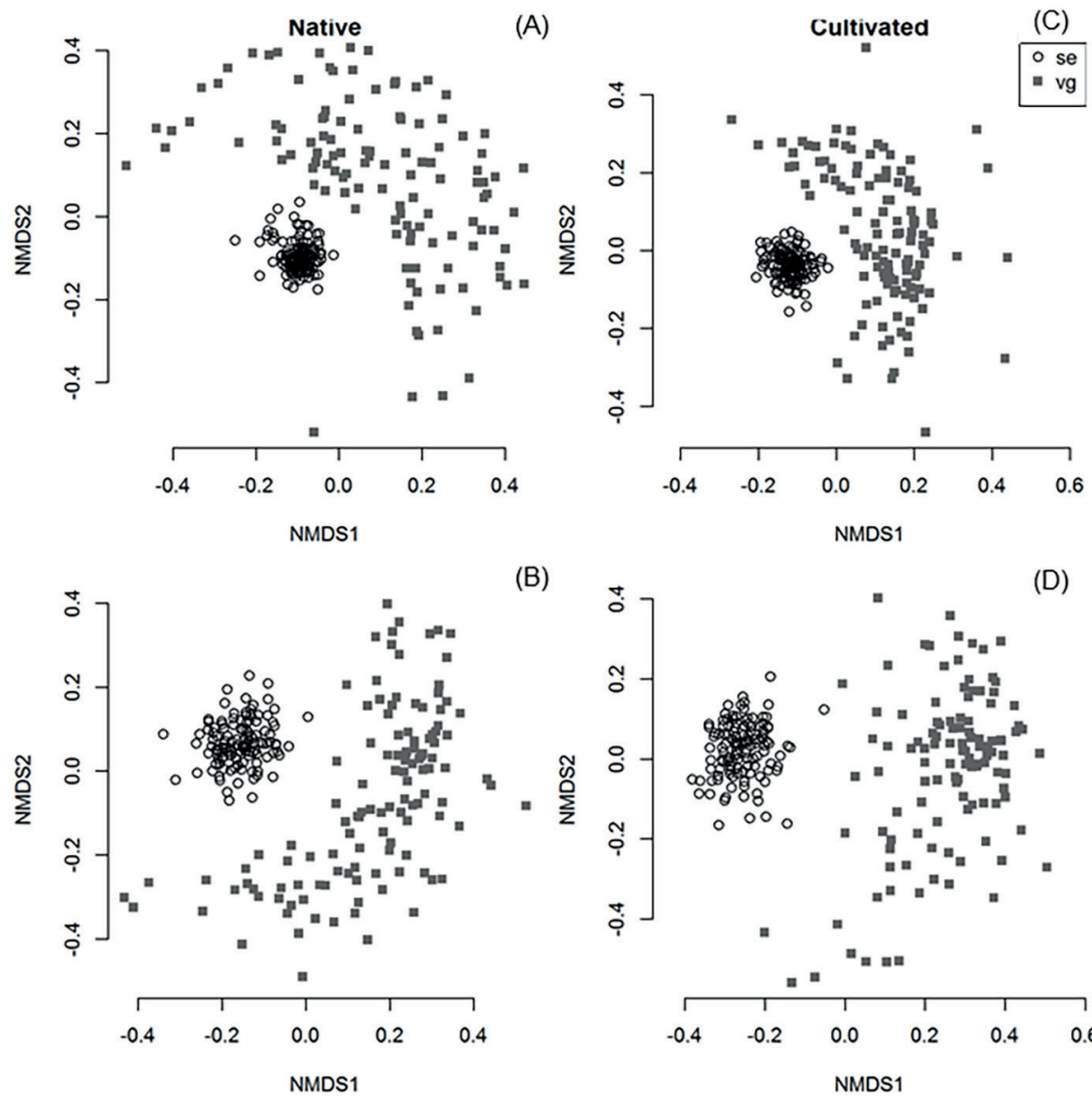

(B)

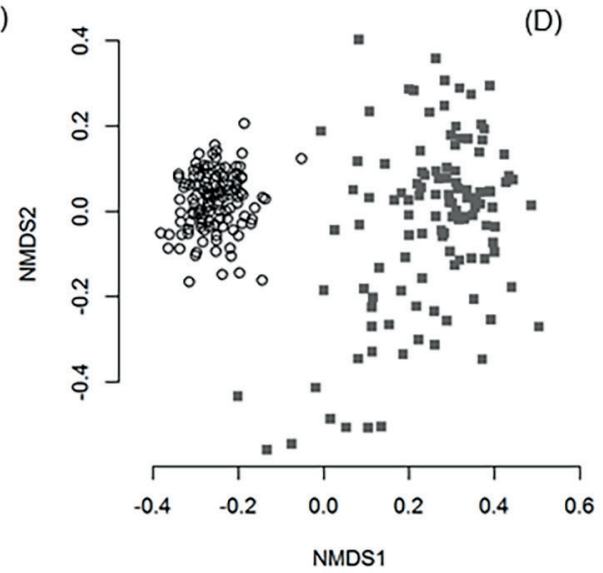

Figure 3. Ordination by non-metric multidimensional scaling (NMDS) of species similarity (Bray-Curtis index), calculated from the abundance and relative cover of species in the seed bank (se) and in the vegetation (vg), in native grassland in (A) flood and (B) dry seasonal periods and grassland dominated by U. humidicola in (C) flood and (D) dry seasonal periods, in the Pantanal wetland (Central-West Brazil).

Table 1. Analysis of variance of the Shannon diversity index between the seed bank and the vegetation (SE \pm mean), in native and cultivated grassland in the flood and the dry seasonal periods (Central-West Brazil).

\begin{tabular}{|c|c|c|c|c|c|c|}
\hline Grassland & & Vegetation & Seed bank & Df & $F$ & $\mathbf{P}$ \\
\hline \multirow{5}{*}{ Native } & Season & & & & & \\
\hline & Flood & $0.5060 \pm 1.2559$ & $0.4341 \pm 2.7781$ & 1 & 508 & 0.001 \\
\hline & Dry & $0.3896 \pm 1.2721$ & $0.4158 \pm 2.4228$ & 1 & 408 & 0.001 \\
\hline & flood+dry & $0.7561 \pm 1.8770$ & $0.4514 \pm 2.5773$ & 2 & 876 & 0.001 \\
\hline & Residuals & & & 223 & & \\
\hline \multirow{4}{*}{ Cultivated } & Season & & & & & \\
\hline & Dry & $0.4089 \pm 1.2411$ & $0.3285 \pm 2.3431$ & 1 & 630 & 0.001 \\
\hline & flood+dry & $0.7448 \pm 1.9342$ & $0.4225 \pm 2.5605$ & 2 & 962 & 0.001 \\
\hline & Residuals & & & 223 & & \\
\hline
\end{tabular}



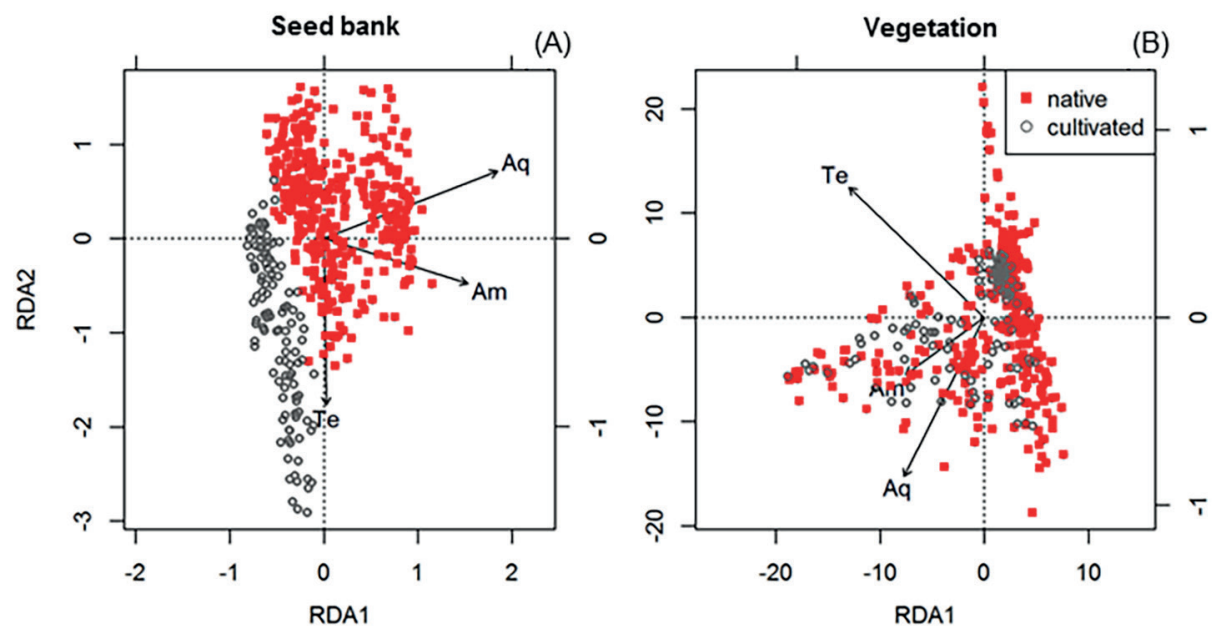

Figure 4. Redundancy Analysis (RDA) of the distribution of distinct growth forms in the (A) seed bank and (B) in the vegetation of the plots of native and cultivated grassland (Central-West Brazil). The ordination was based on data of abundance and relative cover of the species. $\mathrm{Aq}=$ aquatic; $\mathrm{Am}=$ amphibious and $\mathrm{Te}=$ terrestrial.

\section{Discussion}

\section{Floristics}

The characteristics of the vegetation and the seed bank were studied in grasslands with native and cultivated grasses. The predominance of annual species in the seed bank and the vegetation indicates high turnover promoted by the seasonal environments in the vegetation. The seasonal effect can be the main source of similarity between types of grasslands. The highest richness and abundance in the seed bank was also observed in other floodable grasslands due to a large production of annual seeds tolerating the flood periods (Brock et al. 2003; Ma et al. 2012). Such tolerance of the seeds makes the seed banks one of the primary sources of maintenance of wetland diversity (Ge et al. 2013).

In seasonal grasslands, when waters recede and fields begin to dry, annual species are the first to germinate (Bao et al. 2014; 2018b), then several native and exotic grasses start (Bao et al. 2015; 2018a). In contrast, in the flood season, the aquatic plants that were waiting for more moisture compose the vegetation (Agra \& Ne'eman 2012). This dynamics of vegetation is only possible due to the persistent seed bank that offers higher resilience to the environment (Brock 2011). Thereby, such areas under recurrent floods tend to present higher proportion of annual species in the seed banks and lower similarity with the established vegetation.

The lower species richness in vegetation compared with the seed bank can be due to the high mean plant cover of perennial grasses in native grassland (ca. 55\%) and cultivated with dominant $U$. humidicola (ca. $70 \%$ ). In grasslands, the dominance of a species leads to reduced germination of species with germinative characteristics below the dominant one (Myers et al. 2005). This fact can explain the high richness of annual plants in the vegetation, where such species are initial colonizers (Scott \& Morgan 2012), present fast germination and reproduction, independently on the stressing environmental conditions (McPeek \& Peckarsky 1998). However, the perennial species tend to have late germination and show low seed production (Gillespie \& Volaire 2017), which caused low occurrence of perennial species in the seed bank.

\section{Similarity and diversity}

Our results show that regardless of the dominance of $U$. humidicola, the seed bank and the vegetation are not similar. The higher diversity of the seed bank during flood seasons assures the survival of several growth forms. Seed banks are known to contain more species richness and diversity than the vegetation properly (Touzard et al. 2002; Ma et al. 2012; Yang \& Li 2013), as they accumulate seeds for many years (Holzel \& Otte 2004). Seed longevity in wetlands is attributed to species-specific germination characteristics (Leeuwen et al. 2014; Baskin \& Baskin 2014).

The vegetation can be limited by the effect of grazing (not evaluated in this study) and by environmental filters, such as flooding (Myers \& Harms 2009; Bao et al. 2015), which promotes loss of species in certain times of the year (Bao et al. 2015). Several terrestrial species without tolerance to submersion drop out the vegetation during the flood season (Yang \& Li 2013), e.g., Eragrostis articulata, E. bahiensis, Panicum repens and Paspalum almum (present in the seed bank in the flood period, Tab. S1 in supplementary material). In contrast, the opposite occurs in the dry period, when the mortality of strictly aquatic plants is due to an intolerance to desiccation (Blindow et al. 2016), e.g., Cabomba furcata, Hetheranthera limosa and Limnocharis flava (abundant in the seed bank during the dry period, Tab. S1 in supplementary material). In this grassland, the species trade-off between seasonal periods only occurred in the vegetation. The seed bank had a similar species composition in both periods. The 
seed bank can remain with high richness and abundance for years, which can be the primary source of maintenance in wetlands.

The differences between vegetation and seed bank are maintained by the higher diversity of the seed bank. It is an efficient regeneration mechanism rich in annual and perennial species that may not exhaust by germination, which is conferred to wetlands areas by the species turnover from the dynamics of flood and dry (Capon et al. 2015). In this way, the seed bank acts as the primary receptor for species (seed income) whilst the vegetation reflects a small part of the hidden community according to environmental conditions. This gives grasslands the resilience needed to withstand floods and competition with exotic species.

\section{Correlation of the seed bank and vegetation in relation to growth forms}

The positive correlation of the distribution of aquatic plant seeds in native grasslnd may indicate that they have a high seed rain and rapid germination. The similarity in requirements of resources for germination becomes favorable (McPeek \& Peckarsky 1998), in addition to the presence of aquatic plants in the vegetation that increases the income of seeds by dispersal and, consequently, increase the abundance of the seed bank of aquatic macrophytes (Metzner et al. 2017).

The negative correlation of aquatic plants seeds on cultivated grassland indicates that a low flow of this growth form is occurring, either for failures in dispersal from nearby grasslands (Miao et al. 2016), or for the low cover of these species in the vegetation, which reduces the income from seed rain (Metzner et al. 2017). The dominance of exotic grass in the vegetation can suppress the growth of submerged macrophytes and leaves of free-floating, due to the reduction of light and nutrients, and can increase soil temperature (Gopal \& Goel 1993; Ot'ahel'ová et al. 2011). Furthermore, the seeds and aerial parts of U. humidicola present allelopathic activity (Souza Filho et al. 2005), which may be inhibiting the germination of aquatic plants, but there are no studies to prove this. In rice fields, it can be observed that where the water extract of roots, stems leaves inhibits the germination of the macrophyte Heteranthera limosa (Ebana et al. 2001).

The lowest abundance of aquatic plants in cultivated grassland is worrying, since they are economically utilized in the control of exotic plants for their capacity to tolerate either flooded or dry soils, in the form of amphibious plants (Barrett et al. 1993), especially by limiting the light they promote with floating leaves (Bao et al. 2020). However the role of the seed bank in the communities of aquatic plants still presents research gaps, given the frequent initial colonization of temporary wetlands requiring a diverse seed bank (Elsey-Quirk \& Leck 2015). Despite the lower distribution of aquatic plants in cultivated grassland, it did not alter the diversity of the seed bank.

\section{Conclusion}

The seed bank demonstrated the potential to predict the richness and abundance of species wetlands, with the higher presence of annual species reflecting the leading composition seed banks in wetlands areas. The seed bank has greater diversity, mainly due to the greater abundance of aquatic and amphibian plants, present in native grasslands. In this case, it was evident that there is a loss of aquatic macrophytes in the cultivated grasslands, which can become particularly important in the formulation of plans to control U. humidicola invasion in native grasslands and neighboring areas, and preserving the Pantanal native plant community.

\section{References}

Allem AC, Valls JFM. 1987. Recursos forrageiros nativos do Pantanal Mato-grossense. Brasília, EMBRAPA-CENARGEN.

Agra H, Ne'eman G. 2012. Composition and diversity of herbaceous patches in woody vegetation: The effect of grazing, soil seed bank, patch spatial properties and scale. Flora 207: 310-317.

APG IV. 2016. An update of the Angiosperm Phylogeny Group classification for the orders and families of flowering plants: APG IV. Botanical Journal of the Linnean Society 181: 1-20.

Baldwin AH, Kettenring KM, Whigham DF. 2010. Seed banks of Phragmites australis -dominated brackish wetlands: relationships to seed viability, inundation, and land cover. Aquatic Botony 93:163-169.

Bao F, Pott A, Ferreira FA, Arruda R. 2014. Soil seed bank of floodable native and cultivated grassland in the Pantanal wetland: effects of flood gradient, season and species invasion. Brazilian Journal of Botany 37: 239-250.

Bao F, Assis MA, Arruda R, Pott A. 2015. Effects of Urochloa humidicola on plant diversity in native grasslands in a Neotropical wetland. Wetlands 35: 841-850.

Bao F, Leandro TD, Rocha M, et al. 2017. Plant species diversity in a Neotropical wetland: patterns of similarity, effects of distance and, altitude. Annals of the Brazilian Academy of Sciences 90: 85-97.

Bao F, Elsey-Quirk T, Assis MA, Pott A. 2018a. Seed bank of seasonally flooded grassland: experimental simulation of flood and post-flood. Aquatic Ecology 52: 93-105.

Bao F, Elsey-Quirk T, Assis MA, Arruda R, Pott A. 2018b. Seasonal flooding, topography, and organic debris in interact to influence the emergence and di'1stribution of seedlings in a tropical grassland. Biotropica 50: 616-624.

Bao F, Elsey-Quirk T, Assis MA, Souza EB, Pott A. 2020. Do aquatic macrophytes limit the invasion potential of exotic species in Pantanal grassland? Wetlands 40: 135-142.

Barrett CH, Eckert CG, Husband BC. 1993. Evolutiary process in aquatic plant populations. Aquatic Botany 44: 105-145.

Baskin C, Baskin J. 2014. Seeds: Ecology, biogeography, and Evolution of dormancy and germination. 2nd edn. Cambridge, Academic Press.

Blindow I, Dahlke S, Dewart A, et al. 2016. Long-term and interannual changes of submerged macrophytes and their associated diaspore reservoir in a shallow southern Baltic Sea bay: influence of eutrophication and climate. Hydrobiologia 778: 121-136.

Boedeltje G, Heerdt GNJ, Bakker JP. 2002. Applying the seedling-emergence method under waterlogged conditions to detect the seed bank of aquatic plants in submerged sediments. Aquatic Botany 72:121-128.

Bonis A, Lepart J, Grillas P. 1995. Seed bank dynamics and coexistence of annual macrophytes in temporary and variable habitat. Oikos 74: 81-92.

Bossuyt B, Butaye J, Honnay O. 2006. Seed bank composition of open and overgrown calcareous grassland soils - a case study from Southern Belgium. Environmental Management Journal 79: 364-371.

Brock MA, Nielsen DL, Shiel RJ, Green JD, Langley JD. 2003. Drought and aquatic community resilience: the role of eggs and seeds in sediments of temporary wetlands. Freshwater Biology 48: 1207-1218.

Brock MA. 2011. Persistence of seed banks in Australian temporary wetlands. Freshwater Biology 56: 1312-1327. 
Capon SJ, Lynch AJJ, Bond N, et al. 2015. Regime shifts, thresholds and multiple stable states in freshwater ecosystems: a critical appraisal of the evidence. Science of the Total Environment 534: 122-130.

Casanova MT, Brock MA. 1990. Charophytes germination and establishment from the seed bank of an australian temporary lake. Aquatic Botany 36: 247-254

Deepayan S. 2008. Lattice: Multivariate Data Visualization with R. New York, Springer.

Dolle M, Schmidt W. 2009. The relationship between soil seed bank, aboveground vegetation and disturbance intensity on old-field successional permanente plots. Applied Vegetation Science 12: 415-428.

Ebana K, Yan W, Dilday RH, Namai H., Okuno K. 2001. Variation in the allelopathic effect of rice with water soluble extracts. Agronomy Journal 93: 12-16.

Elsey-Quirk T, Leck MA. 2015. Patterns of seed bank and vegetation diversity along a tidal freshwater river. American Journal of Botany 102: 1996-2012.

Fisher JL, Loneragan WA, Dixon K, Veneklaas EJ. 2009. Soil seed bank compositional change constrains biodiversity in an invaded speciesrich woodland. Biological Conservation 142: 256-269.

Ge XL, Liu J, Wang RQ. 2013. Effects of flooding on the germination of seed banks in the Nansi Lake wetlands, China. Journal Freshwater Ecology 28: 225-237.

Gil ASB, Bove CP. 2006. Eleocharis R.Br. (Cyperaceae) no estado do Rio de Janeiro, Brasil. Biota Neotropica 7: 163-193.

Gillespie LM, Volaire FA. 2017. Are winter and summer dormancy symmetrical seasonal adaptive strategies? The case of temperate herbaceous perennials. Annals of Botany 119: 311-323.

Gopal B, Goel U. 1993. Competition and allelopathy in aquatic plant communities. The Botanical Review 59: 155-210.

Groth D. 1983. Estudo morfológico das unidades de dispersão e respectivas plantas de seis espécies invasoras da família Cyperaceae. Planta Daninha 5: 25-38.

Harwell MC, Havens KE. 2003. Experimental studies on the recovery potential of submerged aquatic vegetation after flooding and desiccation in a large subtropical lake. Aquatic Botany 77: 135-151.

Holzel N, Otte A. 2004. Inter-annual variation in the soil seed bank of flood meadows over two years with different flooding patterns. Plant Ecology 174: 279-291.

Kaul RB. 1978. Morphology of germination and establishment of aquatic seedlings in Alismataceae and Hydrocharitaceae. Aquatic Botany 5:139-147.

Kaul RB. 1985. Reproductive phenology and biology in annual and perennial Alismataceae. Aquatic Botany 22: 153-164.

Kindt R, Coe R. 2005. Tree diversity analysis. A manual and software for common statistical methods for ecological and biodiversity studies. Nairobi, World Agroforestry Centre (ICRAF).

Kissmann KG, Groth D. 1992. Plantas infestantes e nocivas. 2nd. edn. São Paulo, BASF- Badische Anilin \& Soda Fabrik.

Kissmann KG, Groth D. 1997. Plantas infestantes e nocivas. 2nd. edn. São Paulo, BASF- Badische Anilin \& Soda Fabrik.

Kissmann KG, Groth D. 1995. Plantas infestantes e nocivas. 2nd. edn. São Paulo, BASF- Badische Anilin \& Soda Fabrik.

Leeeuwen CHA, Sarneel JM, Paassen J, Rip WJ, Bakker ES. 2014. Hydrology, shore morphology and species traits affect seed dispersal, germination and community assembly in shoreline plant communities. Journal Ecology 102: 998-1007.

Ma M, Zhou X, Ma Z, Du G. 2012. Composition of the soil seed bank and vegetation changes after wetland drying and soil salinization on the Tibetan Plateau. Ecological Engineering 44: 18-24.

Mattos JLS, Gomide JA, Huaman CAM. 2005. Crescimento de espécies do gênero Brachiaria sob alagamento em casa de vegetação. Revista Brasileira de Zoologia 34: 10-16.

Mcfarland DG, Shafer DJ. 2011. Protocol considerations for aquatic plant seed bank assessment. Journal of Aquatic Plant Management 49: 9-19.

McPeek MA, Peckarsky BL. 1998. Life histories and the strengths of species interactions: combining mortality, growth, and fecundity effects. Ecology 79: 867-879.

Metzner K, Gachet S, Rocarpin P, Saatkamp A. 2017. Seed bank, seed size and dispersal in moisture gradients of temporary pools in Southern France. Basic and Applied Ecology 21: 13-22.
Miao R, Song Y, Sun Z, Guo M, Zhou Z, Liu Y. 2016. Soil Seed bank and Plant Community Development in Passive Restoration of Degraded Sandy Grasslands. Sustainability 8: 581-593.

Michelan TS, Thomaz SM, Mormul RP, Carvalho P. 2010. Effects of an exotic invasive macrophyte (tropical signalgrass) on native plant community composition, species richness and functional diversity. Freshwater Biology 55: 1315-1326.

Middleton BA. 2002. Flood Pulsing in Wetlands: Restoring the Natural Hydrological Balance. New York, John Wiley and Sons.

Montorio GA, Braccini AL, Scapim CA, Oliveira VR, Bracini MCL. 1997. Avaliação de métodos para superação da dormência das sementes de capim brachiária (Brachiaria brizantha cv. Marandu). Revista Unimar 19: 797-809.

Myers CV, Anderson RC, Byers DL. 2005. Influence of shading on the growth and leaf photosynthesis of the invasive non-indigenous plant garlic mustard [Alliaria petiolata (M. Bieb) Cavara and Grande] grown under simulated late-winter to mid-spring conditions. The Journal of the Torrey Botanical Society 132: 1-10.

Myers JA, Harms KE. 2009. Seed arrival, ecological filters and plant species richness: a meta-analysis. Ecology Letters 12: 1250-1260.

Nathan R, Muller-Landau HC. 2000. Spatial patterns of seed dispersal, their determinants and consequences for recruitment. Tree 15: 278-285.

Oksanen JF, Blanchet G, Friendly M, Kindt R, Legendre P, McGlinn D, Minchin PR, O’Hara RB, Simpson GL, Solymos P, Stevens MHH, Szoecs E, Wagner ZH. 2017. Vegan: Community Ecology Package. R package version 2: 4-3. https://CRAN.R-project.org/package=vegan. 25 Jan. 2020.

Ot'ahel'ová H, Ot'ahel' J, Pazúr R, Hrivnák R, Valachovic M. 2011. Spatiotemporal changes in land cover and aquatic macrophytes of the Danube floodplain lake. Limnologica 41: 316-324.

Pott A, Pott VJ. 1994. Plantas do Pantanal. Brasília, EMBRAPA.

Pott VJ, Pott A. 2000. Plantas aquáticas do Pantanal. Brasília, EMBRAPA.

Pott A, Pott VJ. 2004. Features and conservation of the Brazilian Pantanal wetland. Wetlands Ecology and Management 12: 547-522.

Pott A, Silva JSV. 2015. Terrestrial and aquatic vegetation diversity of the Pantanal Wetland. In: Bergier I, Assine ML. (eds.) Dynamics of the Pantanal Wetland in South America. Cham, Springer International Publishing Switzerland. p. 111-151.

R Development Core Team. 2020. R: A language and environment for statistical computing. R Foundation for Statistical Computing, Vienna, Austria. https://www.R-project.org/. 25 Jan. 2020.

Scott AJ, Morgan JW. 2012. Germination strategies of annual forbs from South - eastern Australian semiarid grasslands. Australian Journal of Botany 60: 340-351.

Silva JSV, Abdon MM. 1998. Delimitação do Pantanal Brasileiro e suas sub regiões. Pesquisa Agropecuária Brasileira 33: 1703-1711.

Simpson GL. 2016. Permute: functions for generating restricted permutations of data (version $\mathrm{R}$ package version 0.9-4). https:// CRAN.R-project.org/package=permute. 25 Jan. 2020.

Smith AR, Pryer KM, Schuettpelz E, Korall P, Schneider H, Wolf PG. 2006. A classification for extant ferns. Taxon 55: 705-731.

Souza LS, Velini ED, Martins D, Rosolem CA. 2006. Efeito alelopático de capim-braquiária (Brachiaria decumbens) sobre o crescimento inicial de sete espécies de plantas cultivadas. Planta Daninha 24: 657-668.

Souza DKL, Giulietti AM. 2014. Flora da Bahia: Pontederiaceae. SitientibusSérie Ciências Biológicas 14: scb360. doi: 10.13102/scb360

Souza EB, Ferreira FA, Pott A. 2016. Effects of flooding and its temporal variation on seedling recruitment from the soil seed bank of a Neotropical floodplain. Acta Botanica Brasilica 31: 64-75.

Souza Filho APS, Pereira AAG, Bayma JC. 2005. Aleloquímico produzido pela gramínea forrageira Brachiaria humidicola. Planta Daninha 23: 25-32.

Thompson K, Bakker JP, Bekker R.M., 1997. The soil seed banks of North West Europe: methodology, density, and longevity. Cambridge, UK, Cambridge University Press.

Touzard B, Amiaud B, Langlois E, Lemauviel S, Clément B. 2002. The relationship between soil seedbank, aboveground vegetation and disturbances in a eutrophic alluvial wetland of Western France. Flora 197: 175-185.

Whittaker RJ, Willis KJ, Field R. 2001. Scale and species richness: towards a general, hierarchical theory of species diversity. Journal of Biogeography 28: 453-470.

Yang D, Li W. 2013. Soil seed bank and aboveground vegetation along a successional gradient on the shores of an oxbow. Aquatic Botany 110:67-77. 